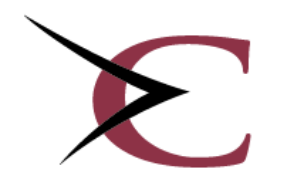

\title{
cirano
}

Allier savoir et décision

$2015 \mathrm{~s}-23$

\section{Securities Transactions Taxes and Financial Crises}

Benoît Carmichael, Jean Armand Gnagne, Kevin Moran 
2015s-23

\title{
Securities Transactions Taxes and Financial Crises
}

\author{
Benoît Carmichael, Jean Armand Gnagne, Kevin Moran
}

\begin{tabular}{c}
\hline Série Scientifique \\
Scientific Series
\end{tabular}

\section{Montréal \\ Juin 2015}

(C) 2015 Benoît Carmichael, Jean Armand Gnagne, Kevin Moran. Tous droits réservés. All rights reserved. Reproduction partielle permise avec citation du document source, incluant la notice $($ ).

Short sections may be quoted without explicit permission, if full credit, including (C) notice, is given to the source.
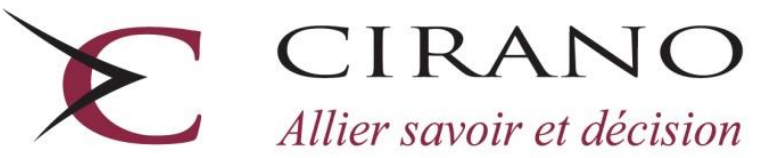

Allier savoir et décision

Centre interuniversitaire de recherche en analyse des organisations 


\section{CIRANO}

Le CIRANO est un organisme sans but lucratif constitué en vertu de la Loi des compagnies du Québec. Le financement de son infrastructure et de ses activités de recherche provient des cotisations de ses organisations-membres, d'une subvention d'infrastructure du Ministère de l'Économie, de l'Innovation et des Exportations, de même que des subventions et mandats obtenus par ses équipes de recherche.

CIRANO is a private non-profit organization incorporated under the Québec Companies Act. Its infrastructure and research activities are funded through fees paid by member organizations, an infrastructure grant from the Ministère de l' l'Économie, de l'Innovation et des Exportations, and grants and research mandates obtained by its research teams.

\section{Les partenaires du CIRANO}

Partenaire majeur

Ministère de l'Économie, de l'Innovation et des Exportations

\section{Partenaires corporatifs}

Autorité des marchés financiers

Banque de développement du Canada

Banque du Canada

Banque Laurentienne du Canada

Banque Nationale du Canada

Bell Canada

BMO Groupe financier

Caisse de dépôt et placement du Québec

Fédération des caisses Desjardins du Québec

Financière Sun Life, Québec

Gaz Métro

Hydro-Québec

Industrie Canada

Intact

Investissements PSP

Ministère des Finances du Québec

Power Corporation du Canada

Rio Tinto Alcan

Ville de Montréal

\section{Partenaires universitaires}

École Polytechnique de Montréal

École de technologie supérieure (ÉTS)

HEC Montréal

Institut national de la recherche scientifique (INRS)

McGill University

Université Concordia

Université de Montréal

Université de Sherbrooke

Université du Québec

Université du Québec à Montréal

Université Laval

Le CIRANO collabore avec de nombreux centres et chaires de recherche universitaires dont on peut consulter la liste sur son site web.

Les cahiers de la série scientifique (CS) visent à rendre accessibles des résultats de recherche effectuée au CIRANO afin de susciter échanges et commentaires. Ces cahiers sont écrits dans le style des publications scientifiques. Les idées et les opinions émises sont sous l'unique responsabilité des auteurs et ne représentent pas nécessairement les positions du CIRANO ou de ses partenaires.

This paper presents research carried out at CIRANO and aims at encouraging discussion and comment. The observations and viewpoints expressed are the sole responsibility of the authors. They do not necessarily represent positions of CIRANO or its partners.

ISSN 2292-0838 (en ligne) 


\title{
Securities Transactions Taxes and Financial Crises ${ }^{*}$
}

\author{
Benoît Carmichael ${ }^{\dagger}$, Jean Armand Gnagne ${ }^{*}$, Kevin Moran $^{\S}$
}

\section{Résumé/abstract}

This paper assesses the impact that a widely-based Securities Transaction Tax (STT) could have on the likelihood of systemic financial crises. We apply the methodology developed by Demirgüç-Kunt and Detragiache (1998) [IMF Staff Papers 45 (1)] to a panel dataset of 34 OECD countries for the sample 1973-2012, using a measure of a country's average bid-ask spread in financial markets as a proxy for the likely effect of a STT on transactions costs. Our results indicate that the establishment of a STT could sizeably increase the risk of financial crises.

Mots clés/keywords : Securities Transaction Tax, Tobin Tax, Regulation, Financial crises

Codes JEL/JEL Codes : E130, G150, G170

\footnotetext{
* We thank Vincent Boucher and Carlos Ordas Criado, as well as participants at the 2014 CEA Annual Conference, for useful comments and discussions. We remain responsible for any errors and omissions.

†Université Laval.

*Université Laval.

${ }^{\S}$ Université Laval et CIRANO, kevin.moran@ecn.ulaval.ca
} 


\section{Introduction}

The global environment for regulating financial markets and institutions is undergoing important changes. Motivated by the severe worldwide crisis of 2008-2009, these changes aim to make financial markets more resilient and lessen the likelihood of systemic crises occurring in the future. ${ }^{1}$

In this context, the establishment of a Securities Transaction Tax (STT), an ad-valorem tax on many financial transactions, has generated renewed interest. An ongoing policy effort initiated by the European Commission aims to introduce such a tax across the European Union and has two stated goals: increase the resilience of European financial markets and generate revenue that could help share the burden of future support to troubled financial institutions. Assessing the likely impact of a EU-wide STT is challenging however, because no widely-based such tax presently exist; in turn, this uncertainty has slowed down the implementation process of the EU STT considerably. ${ }^{2}$

To contribute to this debate, the present paper assesses the likely impact of a STT on the likelihood of systemic financial crises, using the methodology in Demirgüç-Kunt and Detragiache (1998). A binary financial crisis variable is constructed and a logit model for determining the probability of crisis is formulated. The model is estimated using a panel dataset for the 34 OECD countries covering the sample $1973-2012$. We develop a measure of the average bid-ask spread in a country's financial markets and use it as a proxy for the likely impact of a STT on transaction costs and we include this proxy to the model's explanatory variables.

Our results uncover a positive, statistically as well as economically significant relationship between our proxy for the STT and the likelihood of crisis; said otherwise, high transactions costs are associated with higher risks of financial crises. Our benchmark specification reports that the odds of experiencing a crisis doubles following a unit-increase in the proxy and our sensitivity analysis shows that this effect may be as large as a five-fold increase in those odds. These results therefore suggest that the implementation of a EUwide STT could increase the likelihood of financial crisis and are distinctly at variance with the effect envisaged by the EU proposal.

Previous work analyzing the economic impacts of STTs has tended to concentrate on aspects of financial markets performance conceptually different than the occurrence of crises, such as market volatility or trading volumes (Jackson and O'Donnell, 1985; Roll, 1989; Umlauf, 1993; Saporta and Kan, 1997; Pomeranets and Weaver, 2011). In addition, this literature has often focused on specific countries and/or historical episodes. The

\footnotetext{
${ }^{1}$ Regulatory changes under consideration or already enacted include increased capital requirements for banks, tighter limits on loan-to-value ratios, as well as new "macroprudential" policies.

${ }^{2}$ Initially expected by 1 January 2014, the EU STT continues to be debated and controversies over its scope and practical implementation details remain.
} 
present paper adopts a complementary strategy and examines a large panel of countries over a constant historical sample, in order to filter out country or time-specific factors and help establish the likely impact of an area-wide tax like the EU STT.

Our panel-data approach is also related to an important body of work analyzing the key determinants of banking, exchange rate, or financial crisis: in addition to DemirgüçKunt and Detragiache (1998), this literature includes work by Kaminsky and Reinhart (1999), Borio and Lowe (2002), Bussiere and Fratzscher (2006), Davis and Karim (2008) and Schularick and Taylor (2012). In contrast to this literature, however, the present paper focuses on Securities Transaction Taxes and their likely macrofinancial effects.

The remainder of this paper is organized as follows. Section 2 presents a short discussion of the literature on securities transactions taxes and the manner in which they might affect volatility and resilience in financial markets. Section 3 then presents the econometric model, while section 4 describes the data, providing details on how we construct the crisis variable and the proxy for the impact of STTs on transaction costs. Section 5 presents our results and discusses their significance, while section 6 concludes.

\section{Securities Transactions Taxes}

Establishing an ad-valorem tax on some or all financial transactions was originally proposed by Keynes to reduce what he considered excess volatility and disruptive speculation in financial markets. The likely macroeconomic and financial impacts of this type of tax has been the subject of a lively academic literature ever since. ${ }^{3}$

Proponents of STTs (Tobin, 1978; Stiglitz, 1989; Summers and Summers, 1989) have argued that these taxes can stabilize financial markets and increase their resilience because they penalize trades that reflect non-informed views or short-term (speculative) investing horizons. More skeptical views are advanced by Kupiec (1996) and Amihud and Mendelson (2003), among others, who remark that a STT also discourages trades by informed traders, which can have stabilizing influences on financial markets by providing the liquidity that allows non-informed trading and limits its impact on prices. ${ }^{4}$

Empirical studies on the impacts of STTs have also obtained mixed results. Most notably, difference-in-difference econometric approaches have been developed to contrast the behavior of stocks traded on an exchange subject to a STT (or a proxy therein) with the behavior of comparable stocks trading on another exchange where the tax does not apply. Some of these studies (Umlauf, 1993; Jones and Seguin, 1997; Pomeranets and Weaver, 2011) report that STTs have adverse effects on markets, increasing volatility or

\footnotetext{
${ }^{3}$ See Pomeranets (2012) for a review of this literature.

${ }^{4}$ Kupiec (1996) interprets a STT as acting on "...the symptom of market dysfunction-excess trading volume-" while doing nothing "...to alleviate the cause of the excess volatility-the noise trader's expectational difference of opinion".
} 
lowering liquidity; others, by contrast, report no significant deleterious effects on financial markets from the imposition of STTs (Saporta and Kan, 1997; Becchetti et al., 2013; Capelle-Blancard and Havrykchyk, 2014).

Although the potential of STTs for reducing the likelihood of systemic crises has always been at the forefront of policy discussions, empirical examinations of this type of tax has often concentrated on financial outcomes (like liquidity, or within-period volatility) that are only indirectly liked to crises. This paper aims to complement the extent literature by explicitly considering if STTs impact the likelihood of systemic crises.

\section{Methodology}

To assess the potential link between a STT and the probability of financial crises, we adopt the approach developed by Demirgüç-Kunt and Detragiache (1998). In this context, denote $Y_{i t}$ the binary variable indicating whether country $i$ at time $t$ experiences a crisis $\left(Y_{i t}=1\right)$ or not $\left(Y_{i t}=0\right)$. A logistic approach is used whereby

$$
\operatorname{Prob}\left(Y_{i t}=1\right)=F\left(\beta^{\prime} X_{i t}\right)=\frac{e^{\beta^{\prime} X_{i t}}}{1+e^{\beta^{\prime} X_{i t}}}
$$

where $X_{i t}$ is a $(k \cdot 1)$ vector of explanatory variables for country $i$ at time $t$, and $\beta$ is the $(k \cdot 1)$ vector of associated coefficients. Parameters of the model are estimated by maximizing the sample likelihood

$$
\log L=\sum_{i} \sum_{t}\left[Y_{i t} \log F\left(\beta^{\prime} X_{i t}\right)+\left(1-Y_{i t}\right) \log \left(1-F\left(\beta^{\prime} X_{i t}\right)\right)\right] .
$$

In the data described below, financial crises are rare and some countries (Canada, for example) are found not to have experienced any crisis during the historical period reflected in our sample $(1973-2012)$. In such a case, the logit function for $F(\cdot)$ precludes the addition of (country) fixed effects to the model because one variable (the fixed effect) could be sufficient to perfectly predict the dependent variable for the countries with no crisis (Greene, 2012). We therefore abstain from including fixed-effects and pool all data. ${ }^{5}$

Recall that in the logistic model (1), the sign of a parameter correctly indicates the direction of the probability change but its magnitude is not the marginal impact, which is a non-linear function of all explanatory variables. As a result, the impact of a change in a given explanatory variable is not be the same across countries and periods in our sample: rather, it is smallest in country-period pairs with very low or very high initial crisis probability and highest for intermediate initial probabilities.

\footnotetext{
${ }^{5}$ Alternatively, a probit model with random effects would require assuming that random effects are uncorrelated with regressors. See Demirgüç-Kunt and Detragiache (1998) for a discussion.
} 
In this context, a useful gauge of an estimate's economic significance is the change in the odds ratio, which we denote $\triangle O R$, that measures how much a unit-change in a given explanatory variable modifies the odds of observing a crisis. It obtains that for any explanatory variable $k$,

$$
\Delta O R=e^{\beta_{k}}=\frac{\operatorname{Prob}\left(Y_{i t}=1 \mid \overline{X_{i t k}}+1\right)}{\operatorname{Prob}\left(Y_{i t}=0 \mid \overline{X_{i t k}}+1\right)} / \frac{\operatorname{Prob}\left(Y_{i t}=1 \mid \overline{X_{i t k}}\right)}{\operatorname{Prob}\left(Y_{i t}=0 \mid \overline{X_{i t k}}\right)} .
$$

Below, we discuss the economic significance of our results by referring to $\triangle O R$.

Once a crisis occurs in a country, it very likely produces an endogenous response of its economy and could introduce an inverse causality loop between our dependent and explanatory variables. To limit the extent of this problem, we follow Demirgüç-Kunt and Detragiache (1998) and report results based on two samples. This first excludes all observations from one country after the onset of the first crisis affecting that country. The disadvantage of this strategy is that it eliminates data and does not allow the model to incorporate multiple crises episodes that may have affected some countries. Our second sample therefore deletes only country observations occurring during the period of the crisis and starts recording data once it has abated: if a crisis occurs from 2008 to 2009, say, observations for those years are not included but those prior to 2007 and from 2010 onwards are.

\section{Data}

Our dataset covers the 34 OECD countries over the period $1973-2012$ and the data are annual. ${ }^{6}$ The dependant variable - the occurrence of a financial crisis- is binary and takes value 1 if a crisis is experienced and 0 otherwise. Explanatory variables are from the financial and macroeconomic realm and are similar to those used in the related literature. We construct a proxy for the likely impact of a STT on transaction costs by using annual averages of bid-ask spreads in the financial markets of all the countries in our sample.

\subsection{Dependent Variable}

One influential definition for what constitutes a financial crisis characterizes it as a profound disruption of financial markets whose symptoms include sharp declines in assets price and the failure of many financial and non financial firms (Eichengreen and Portes, 1987). To operationalize this definition, we use historical data on banking crises constructed by

\footnotetext{
${ }^{6}$ Restricting the analysis to OECD countries, a group of relatively homogenous and advanced countries, is an appropriate strategy when discussing the EU STT tax, which would similarly be applied to a group of relatively homogenous countries.
} 
Laeven and Valencia (2012) and data on stock market indexes from Datastream. Specifically, we code the presence of a financial crisis when a banking crisis occurs according to Laeven and Valencia (2012) and when stock markets in the country decline by a predetermined threshold (we experiment with declines of 20\%,25\%, and 50\%). Considering that a STT would arguable affect asset markets more than the banking sector, we consider it important to use a crisis definition that records dysfunctional behavior in both sectors.

This definition requires that both the banking sector and asset markets experience challenging conditions before a financial crisis is considered to be occurring. As a result, financial crises are relatively rare events in the OECD data. Table 1 provides some descriptive statistics, and shows that some countries (e.g. Canada) are not considered to have experienced a financial crisis in the $1973-2012$ period, whereas countries like the United States are considered to have experienced very few. In total, 28 crisis events are recorded for the 34 OECD countries when the threshold decline in assets prices is $20 \%$, and only 15 crisis when a decline of $50 \%$ in asset prices is used to define a crisis. To further assess the sensitivity of our results, we also estimate our model using only the banking crisis indicators from Laeven and Valencia (2012) (38 crisis events are then recorded); this last case compares directly to those in the literature (Demirgüç-Kunt and Detragiache, 1998; Borio and Lowe, 2002; Davis and Karim, 2008). Importantly, results in Section 4 show that our key result - the positive association between our STT proxy and the likelihood of crisis- is robust to the changes in the measurement of crises.

\subsection{Explanatory Variables}

\section{STT index}

Since no homogenous STT currently applies to a large group of countries, a proxy for its effect needs to be developed for the analysis to proceed. One likely practical effect of establishing the EURO-STT would be to raise the gap between prices paid by buyers and those received by sellers of financial assets. We therefore analyze the possible impact of a STT on the probability of crisis by using a proxy constructed from transactions cost. To this end, we use the reported bid-ask spreads on the thirty biggest companies of every country in our sample to construct an annual transactions costs index. ${ }^{7}$

Specifically, our STT proxy for country $i$ at time $t$ is constructed as

$$
S T T_{i t}=\sum_{j} \frac{D_{j i t}}{D_{i t}}\left(\frac{P A_{j i t}-P B_{j i t}}{P B_{j i t}}\right),
$$

where $P A_{j i t}$ and $P B_{j i t}$ are the Ask and Bid prices for firm $j$ of country $i$ in year $t$, and $D_{i j t}$ is the firm's capitalization; $D_{i t}$ is the aggregate market capitalization for all firms

\footnotetext{
${ }^{7}$ We use market capitalization to identify the thirty biggest companies in each country and companies are added or deleted from the index as their market capitalization evolves through time.
} 
considered of country $i$ in year $t$. Since Bid-Ask spreads -the market maker's margin on each effective transaction- may include costs related to adverse selection in addition to pure transactions costs, using large firms only in constructing the index is meant to emphasize the presence of the latter in our proxy. ${ }^{8}$

Over the complete sample, average computed transactions costs stand at $1.7 \%$, with a (within-country but across time) average of $2.4 \%$. Considerable heterogeneity exists however: the average figures for the United States and Canada are relatively low $(0.2 \%)$ while corresponding figures for countries like Sweden and Denmark are high.

\section{Other Explanatory Variables}

We follow the literature on the prediction of crisis and consider additional explanatory variables from the macroeconomic and financial realms. First, macroeconomic variables are represented by GDP growth, the inflation rate, and a measure of short-term interest rates, because these variables have been associated to the occurrence of crisis by previous literature. (Demirgüç-Kunt and Detragiache, 1998; Davis and Karim, 2008). ${ }^{9}$

Other explanatory variables are linked to the strength and the depth of a country's banking, credit, and asset markets. On the banking side, we include the ratios of private bank credit, of total bank deposits, and of liquid bank assets to the country's GDP, as well as the net interest margin and operating costs as a ratio of the banking sector's income.

From stock markets, we include Total Stock Market Capitalization and Total Value Traded (both relative to the country's GDP) as well as turnover, transaction volumes as well as intra-period volatility. ${ }^{10}$

\section{$5 \quad$ Results}

Table 3 to 5 present our results. Each table reports our estimate of (2) for two samples and several specifications. As described above, the first sample is constructed by excluding all data from a country once it has been affected by a first crisis, in order to limit potential endogeneity problems; the second sample reflects a less conservative approach that deletes

\footnotetext{
${ }^{8}$ Glosten and Harris (1988) list inventory and adverse selection costs as the two main components of BidAsk spreads, the latter component being larger for firms or stock markets where informational asymmetries are severe. Indices of transactions costs are also analyzed by Stoll and Whaley (1983) and Schultz (1983).

${ }^{9}$ See Demirgüç-Kunt and Detragiache (1998) for an intuitive discussion of the links between these variables and the likelihood of crises. The authors include other macroeconomic variables linked to developments in exchange rates, terms-of-trade, and fiscal positions but do not find these variables have statistically significant impacts on the probability of crises.

${ }^{10}$ Intra-period volatility refers to the standard deviation of the monthly stock index within a year and is therefore conceptually different from the annual change in the stock index level, one of the component in the financial crisis definition.
} 
data only during the years a country is experiencing the crisis and reintroduces the country in the sample once the crisis is over. The six specifications analyzed per sample incorporate the explanatory variables one block at the time (columns (1) to (3)) or simultaneously (columns (4) to (6)). Finally, Table 3, 4, and 5 reflect different measures of the crisis variable: Table 3 illustrates our benchmark measure, wherein a crisis is defined by the presence of a systemic banking crisis and of a general decline of $50 \%$ in asset prices; Table 4 adopts an intermediary position for which a decline of $20 \%$ in asset prices is sufficient to define a crisis; Table 5 reports the consequence of abstracting from asset price declines altogether and keeping only the systemic banking crisis criterion to define financial crises.

In each table, model performance is assessed using four criteria, listed at the bottom of each column. First, "Deviance explained" is a $R^{2}$-equivalent goodness-of-fit measure assessing the value-added of the model in explaining crises, relative to a specification in which only a constant included. The next three measures, -the "Success", "Accuracy" and "Sensibility" rates- report the model's performance in correctly classifying events. To construct them, for each country-period pair, we consider the model's in-sample prediction to be $\widehat{Y_{i t}}=1$ (a crisis event) if $F\left(\widehat{\beta}^{\prime} X_{i t}\right) \geq 0.5$ and $\widehat{Y_{i t}}=0$ (a non-crisis event) if $F\left(\widehat{\beta}^{\prime} X_{i t}\right)<$ 0.5. Using this prediction, the "Success Rate" is the fraction of times the model correctly predicts realized events (be they crisis or no-crisis events), the "Accuracy" rate is the fraction of times the model was correct in predicting a crisis and the "Sensibility" rate is the proportion of realized crises correctly predicted by the model; these latter two measures differ from each other in that "Accuracy" controls for type-II errors while "Sensibility" encompasses errors of type-I.

The key takeaways from Table 3-5 concern the impact of our STT proxy on the likelihood of crises. The estimated coefficients for the STT proxy are positive and generally statistically significant, indicating that a rise in the proxy is associated with a higher risk of financial crisis. These results suggests that the EU-STT could reduce resilience in European financial markets and increase their vulnerability, an outcome at variance with the one of the original intent of the policy. This surprising effect is also economically meaningful: the $\triangle O R$ (second line of each Table) measure indicates that a one standard deviation in the STT proxy increases the odds of experiencing a financial crises by up to fives times (column 5 of Table 3).

Importantly, Tables 3-5 illustrate that our estimates of the importance of STTs are largely robust to how the crisis data is constructed: recall that whereas the left-hand side of each table reflects the case when all data following the first incidence of a crisis are discarded, right-hand sides of the tables refer to the cases for which data from that country is reintroduced in the sample once the crisis is over. Across the two cases, the STT index remains statistically significant and economically meaningful in most specifications, although model performance does decrease somewhat, with the $R^{2}$-like goodness-of-fit 
measure noticeably smaller for the second (right-hand-side) samples.

In addition, the tables show that results remain also robust when alternative definitions for a crisis are considered, with Table 4 reporting the case where a $20 \%$ decline in assets prices is sufficient to code the presence of a crisis and Table 5 pertaining to the case where only banking crisis are used. Overall therefore, the STT index remains positively associated to the likelihood of crisis and remains statistically and economically meaningful in most cases. ${ }^{11}$

Tables 3-5 also report that other macroeconomic and financial control variables importantly affect the probability of crisis. Among them, GDP growth is estimated to reduce the probability of crisis in a sizeable and statistically significant fashion, a result that is present in previous contributions to the literature on crisis prediction (Demirgüç-Kunt and Detragiache, 1998; Kaminsky and Reinhart, 1999; Davis and Karim, 2008). Similarly, high real interest rates are also associated with an increased vulnerability to crises. Interestingly, the rate of inflation is not robustly significant, in contrast to Demirgüç-Kunt and Detragiache (1998). This might be related to the fact that our dataset covers the relatively homogenous countries forming the OECD and inflation was well-anchored in most such countries during a large proportion of the years covered by our sample. ${ }^{12}$

Estimates for the banking variables most often exhibit the signs predicted by the literature. For instance, higher rates of bank credit to GDP raise the likelihood of financial crisis, in line with the literature interpreting crises as being cause by credit booms (Schularick and Taylor, 2012; Borio and Lowe, 2009). Higher bank costs also worsens the resilience of financial markets. However, these estimates most often lack the statistical significance exhibited by the macroeconomic variables discussed above. This might stem from our definition of financial crisis, which requires both banking and asset markets to experience challenging conditions before a crisis is coded. Lessening the importance of asset markets in that definition definition (as reflected in results from Tables 4 and 5) leads to more significant estimates.

Contrasting with the banking variables estimates, those arising from stock markets are often highly significant. Market capitalization decreases the probability of crisis whereas large values of transactions increase that likelihood. Intra-period price volatility is the most significant variable and its positive association with systemic crisis confirms theoretical and empirical work that focuses on a strong relation between higher volatility and financial turmoil (Umlauf, 1993; Jones and Seguin, 1997; Pomeranets and Weaver, 2011).

\footnotetext{
${ }^{11}$ Other specifications tests having been performed include the exclusion of outlier countries from the sample and the inclusion of lagged variables. Our key results remain robust to these sensitivity tests as well. Full results are available from the authors.

${ }^{12}$ Using data from relatively developed countries similar to ours, Schularick and Taylor (2012) also fail to statistically associate inflation to financial crises.
} 


\section{Conclusion}

Proponents of the EU securities transactions tax (STT) have argued that it has the potential to discourage uninformed and disruptive trading and reduce the likelihood of financial crises. Using a logistic approach and a panel dataset covering the period $1973-2012$ for the 34 OECD countries, we show that a proxy for the likely impact of an STT on transactions costs is positively associated with the occurrence of crisis, suggesting that such a tax could increase, rather than decrease, the risk of financial crisis. This effect is present in several empirical specifications analyzed and is economically meaningful. This result might be interpreted in the context of contributions by Kupiec (1996) and Amihud and Mendelson (2003) who argue that STTs, by discouraging informed trading, may have adverse effects on liquidity, volatility and the resilience of financial markets. 


\section{References}

Y. Amihud and H. Mendelson. Effects of a New York state stock transaction tax. Unpublished Manuscript, 2003.

L. Becchetti, M. Ferrari, and U. Trenta. The impact of the French Tobin tax. CEIS Research Paper 266, Tor Vergata University, March 2013.

C. Borio and P. Lowe. Assessing the risk of banking crises. BIS Quarterly Review, December 2002.

C. Borio and P. Lowe. Assessing the risk of banking crises-revisited. BIS Quarterly Review, March 2009.

M. Bussiere and M. Fratzscher. Towards a new early warning system of financial crises. Journal of International Money and Finance, 25:953-973, 2006.

G. Capelle-Blancard and O. Havrykchyk. The impact of the French security transaction tax on market liquidity and volatility. Discussion papers 14007 RIETI., January 2014.

E. P. Davis and D. Karim. Comparing early warning systems for banking crises. Journal of Financial Stability, 4:89-120, 2008.

A. Demirgüç-Kunt and E. Detragiache. The determinants of banking crises in developing and developed countries. IMF Staff Papers, 45:81-109, 1998.

B. Eichengreen and R. Portes. The anatomy of financial crises. NBER Working Paper Series, (2126), January 1987.

L. R. Glosten and L. E. Harris. Estimating the components of the bid/ask spread. Journal of Financial Economics, 21(1):123-142, 1988.

W. H. Greene. Econometric Analysis. Upper Saddle River New Jersey: Prentice-Hall, 7th. ed., 2012.

P. D. Jackson and A. T. O'Donnell. The effects of stamp duty on equity transactions and prices in the UK stock exchange. Discussion Paper no. 25. Bank of England, October 1985.

C. M. Jones and P. H. Seguin. Transaction costs and price volatility: Evidence from commission deregulation. The American Economic Review, 87:728-737, 1997.

G. Kaminsky and C. M. Reinhart. The twin crises: The causes of banking and balanceof-payments problems. The American Economic Review, 89:473-500, 1999. 
P. H. Kupiec. Noise traders, excess volatility, and a securities transations tax. Journal of Financial Services Research, 10:115-129, 1996.

L. Laeven and F. Valencia. Systemic banking crises database: An update. June 2012. IMF Working Paper no.12/163.

A. Pomeranets. Financial transaction taxes: International experiences, issues and feasibility. Bank of Canada Review, Autumn, 2012.

A. Pomeranets and D. G. Weaver. Security transaction taxes and market quality. Bank of Canada Working Paper No. 2011-26, 2011.

R. Roll. Price volatility, international market links, and their implications for regulatory policies. Journal of Financial Services Research, 3(2-3):211-246, 1989.

V. Saporta and K. Kan. The effects of stamp duty on the level and volatility of UK equity prices. Bank of England Working Papers, 1997.

M. Schularick and A. M. Taylor. Credit booms gone bust: Monetary policy, leverage cycles, and financial crises, 1870-2008. The American Economic Review, 102(2):10291061, 2012.

P. Schultz. Transaction costs and the small firm effect: A comment. Journal of Financial Economics, pages 81-88, 1983.

J. Stiglitz. Using tax policy to curb speculative short-term trading. Journal of Financial Services Research, 3:101-115, 1989.

H. R Stoll and E. Whaley. Transaction costs and the small firm effect. Journal of Financial Economics, pages 57-79, 1983.

L. H. Summers and V. P. Summers. When financial markets work too well: A cautious case for a securities transactions tax. Journal of Financial Services Research, 3:261-286, 1989 .

J. Tobin. A proposal for international monetary reform. Eastern Economic Journal, 4: 153-159, 1978.

S. R. Umlauf. Transaction taxes and the behavior of the swedish stock market. Journal of Financial Economics, 33:227-240, April 1993. 
Table 1 - Descriptive Statistics for the variable "Financial Crises"

\begin{tabular}{|c|c|c|c|c|c|c|c|c|c|}
\hline \multirow{3}{*}{ Period } & \multicolumn{9}{|c|}{ Number of Financial Crises when Defined with Decline in Asset Prices of: } \\
\hline & \multicolumn{3}{|c|}{$20 \%$} & \multicolumn{3}{|c|}{$25 \%$} & \multicolumn{3}{|c|}{$50 \%$} \\
\hline & USA & Canada & OECD & 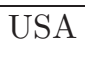 & Canada & OECD & USA & Canada & OECD \\
\hline $1973-1980$ & 0 & 0 & 0 & 0 & 0 & 0 & 0 & 0 & 0 \\
\hline $1981-1990$ & 0 & 0 & 2 & 0 & 0 & 1 & 0 & 0 & 0 \\
\hline $1991-2000$ & 0 & 0 & 7 & 0 & 0 & 6 & 0 & 0 & 3 \\
\hline $2001-2011$ & 1 & 0 & 19 & 1 & 0 & 19 & 0 & 0 & 12 \\
\hline Total & 1 & 0 & 28 & 1 & 0 & 26 & 0 & 0 & 15 \\
\hline
\end{tabular}

Source: Author's calculations

Table 2 - Definition and source of variables

\begin{tabular}{llr}
\hline Variable & Definition & Source \\
\hline $\begin{array}{l}\text { Dependent Variables } \\
\text { Banking Crisis } \\
\text { Asset prices declines }\end{array}$ & $\begin{array}{l}\text { Significant banking system distresses } \\
\text { Annual stock market indexes variations } \\
\text { STT Index }\end{array}$ & IMF \\
Macroeconomic Variables & Deighted Average of bid-ask spreads \\
GDP Growth & Real GDP growth rate & Datastream \\
Inflation & Consumer Price Index growth rate & \\
Real Interest Rate & Real 3-Month Treasury Bill Rate & OECD \\
Banking Variables & & OECD \\
$\begin{array}{l}\text { Private Credit } \\
\text { Total deposits }\end{array}$ & OECD \\
Liquid Assets & Deposit to private sector as a ratio of GDP & \\
Net Interest & Bank Cash and Liquid Securities to GDP & OECD \\
Bank Costs & Bank Margin Rate & OECD \\
Stock Market Variables & Bank Costs as a Ratio of Sector's Income & OECD \\
Capitalization & & OECD \\
Value Traded & OECD \\
Stock Turnover & Stock market Capitalization to GDP & \\
Price Volatility & Value of Stock Market Transactions to GDP & Datastream \\
\hline
\end{tabular}


Table 3 - Estimation Results: Benchmark Measure of Financial Crisis

\begin{tabular}{|c|c|c|c|c|c|c|c|c|c|c|c|c|c|c|c|c|c|c|c|c|c|c|c|}
\hline & \multicolumn{12}{|c|}{$\underline{\text { Sample } 1}$} & \multicolumn{11}{|c|}{$\underline{\text { Sample } 2}$} \\
\hline & $(1)$ & & $(2)$ & & $(3)$ & & (4) & & $(5)$ & & (6) & & $(1)$ & $(2)$ & & (3) & & $(4)$ & & $(5)$ & & $(6)$ & \\
\hline \multicolumn{24}{|c|}{ Transactions Costs } \\
\hline STT Index & 0.4 & $* * *$ & 0.5 & ** & 0.4 & $* * *$ & 0.4 & ** & 0.5 & * & 0.4 & * & 0.2 & 1.6 & ** & 0.2 & & 0.2 & & 1.6 & ** & 1.0 & * \\
\hline$\Delta O R$ & 1.5 & & 1.6 & & 1.5 & & 1.5 & & 1.6 & & 1.5 & & 1.2 & 5.0 & & 1.2 & & 1.2 & & 5.0 & & 2.7 & \\
\hline \multicolumn{24}{|c|}{ Macroeconomic Variables } \\
\hline GDP Growth & -0.9 & ${ }^{* * *}$ & - & & - & & -0.5 & & -1.0 & ** & -0.2 & & -0.6 & - & & - & & -0.2 & & -0.8 & * & -0.1 & \\
\hline Inflation & -0.8 & & - & & - & & -4.3 & & 3.0 & & 1.5 & & 0.7 & - & & - & & -0.9 & & 4.3 & & 3.9 & \\
\hline Real Interest Rate & 1.6 & & - & & - & & 0.8 & & 7.8 & * & -0.6 & & 4.0 & - & & - & & 5.4 & & 8.6 & $*$ & 3.2 & \\
\hline \multicolumn{24}{|c|}{ Banking Variables } \\
\hline Private Credit & - & & 0.3 & & - & & - & & 0.2 & & 1.1 & & - & 0.3 & & - & & - & & 0.0 & & 0.5 & \\
\hline Total deposits & - & & -3.7 & & - & & - & & -4.0 & & - & & - & -4.2 & & - & & - & & -4.7 & & - & \\
\hline Liquid Assets & - & & 3.1 & & - & & - & & 3.5 & & 1.2 & & - & 3.5 & & - & & - & & 4.2 & & 0.6 & \\
\hline Net Interest & - & & -0.1 & & - & & - & & -0.3 & & - & & - & -0.2 & & - & & - & & -0.7 & & - & \\
\hline Bank Costs & - & & 0.0 & & - & & - & & -0.0 & & - & & - & 0.1 & & - & & - & & -0.1 & & - & \\
\hline \multicolumn{24}{|l|}{ Stock Markets } \\
\hline Capitalization & - & & - & & -2.3 & ** & -1.0 & & - & & -4.1 & ${ }_{* *}^{*}$ & - & - & & -2.1 & ** & -0.7 & & - & & -1.8 & \\
\hline Value Traded & - & & - & & 1.9 & * & - & & - & & 2.3 & & - & - & & 1.8 & $* *$ & - & & - & & 1.2 & \\
\hline Stock Turnover & - & & - & & -1.1 & & 0.4 & & - & & -1.9 & & - & - & & -1.1 & & 0.5 & & - & & -0.9 & \\
\hline Price Volatility & - & & - & & 0.7 & $* * *$ & 0.7 & $* * *$ & - & & 0.8 & $* * *$ & - & - & & 0.6 & $* * *$ & 0.7 & $* * *$ & - & & 0.7 & $* * *$ \\
\hline Dev. Expl. (\%)* & 15.3 & & 13.2 & & 41.5 & & 39.7 & & 25.9 & & 48.2 & & 7.3 & 12.3 & & 32.0 & & 29.6 & & 22.5 & & 36.3 & \\
\hline Success Rate ${ }^{\dagger}$ & 97.1 & & 96.6 & & 97.3 & & 96.9 & & 96.6 & & 97.4 & & 97.3 & 97.1 & & 97.7 & & 97.0 & & 97.1 & & 97.4 & \\
\hline Accuracy & 100 & & 100 & & 66.7 & & 60.0 & & 100 & & 75.0 & & 0.0 & 100 & & 75.0 & & 50.0 & & 100 & & 66.7 & \\
\hline Sensibility ${ }^{\S}$ & 11.1 & & 14.3 & & 44.4 & & 33.3 & & 14.3 & & 37.5 & & 0.0 & 14.3 & & 33.3 & & 11.1 & & 14.3 & & 25.0 & \\
\hline
\end{tabular}

Notes: Maximum likelihood estimates of equation (2). Symbols ${ }^{*},{ }^{* *}$ and ${ }^{* * *}$ indicate statistical significance of a parameter at the $10 \%, 5 \%$ and $1 \%$ levels, respectively. $\triangle O R$ is the change in the odds ratio resulting from a one-unit change in STT.

* "Deviance Explained" Goodness of Fit Criterion.

$\dagger$ Fraction of events (No Crisis or Crisis) correctly predicted by the model.

$¥$ Fraction crisis predictions that were realized.

$\S$ Fraction of realized crises correctly predicted by the model 
Table 4 - Estimation Results: Alternative Measure of Financial Crisis

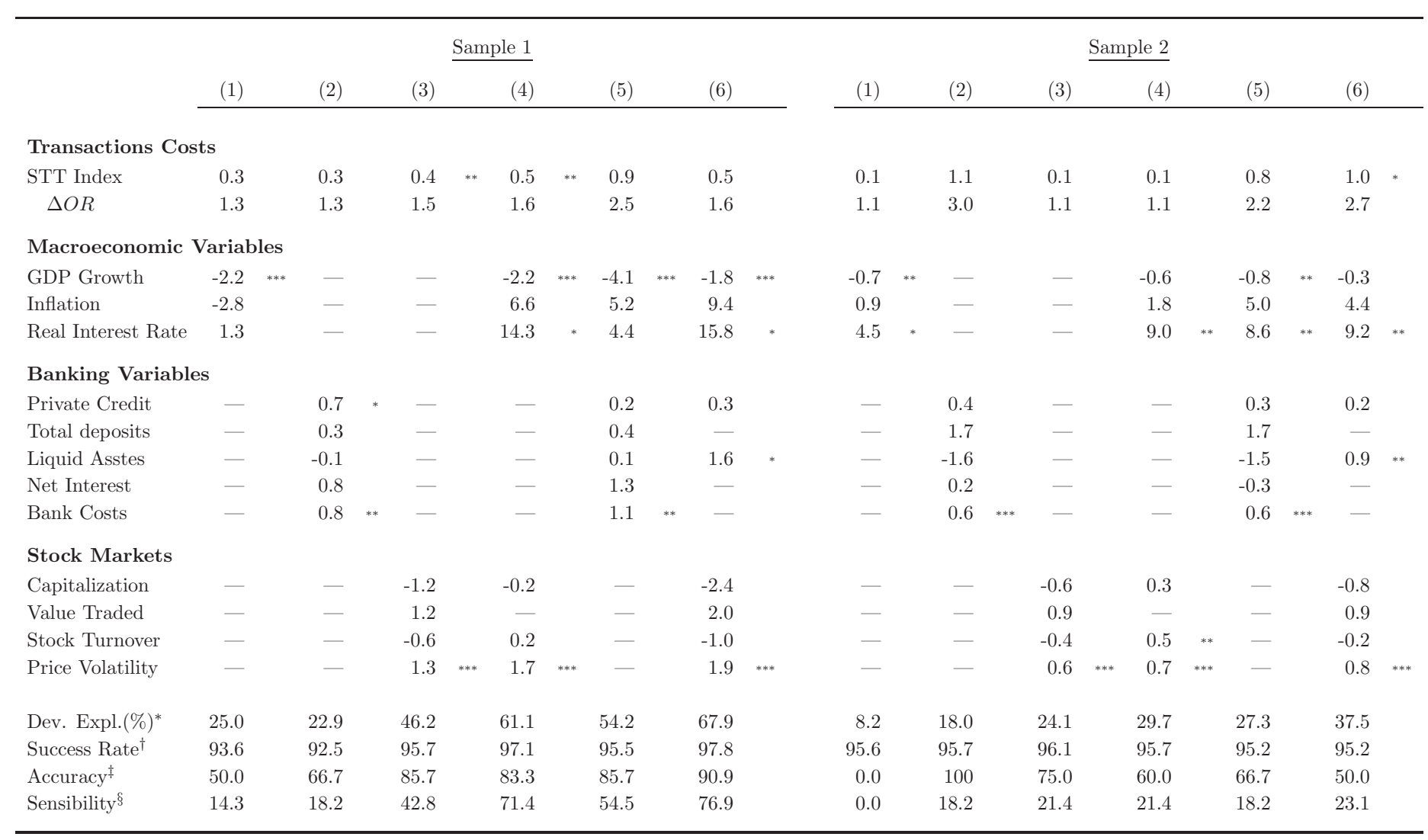

Notes: Maximum likelihood estimates of equation (2). Symbols ${ }^{* * *}$ and ${ }^{* * *}$ indicate statistical significance of a parameter at the $10 \%, 5 \%$ and $1 \%$ levels, respectively. $\triangle O R$ is the change in the odds ratio resulting from a one-unit change in $S T T$.

* "Deviance Explained" Goodness of Fit Criterion.

$\dagger$ Fraction of events (No Crisis or Crisis) correctly predicted by the model.

$\ddagger$ Fraction crisis predictions that were realized.

$\S$ Fraction of realized crises correctly predicted by the model. 
Table 5 - Estimation Results: Alternative Measure of Financial Crisis

\begin{tabular}{|c|c|c|c|c|c|c|c|c|c|c|c|c|c|c|c|c|c|c|c|c|c|c|c|}
\hline & & & & & Samp & le 1 & & & & & & & & & & & $\underline{\text { Sam }}$ & ple 2 & & & & & \\
\hline & $(1)$ & $(2)$ & & $(3)$ & & $(4)$ & & $(5)$ & & (6) & & (1) & & $(2)$ & & (3) & & $(4)$ & & $(5)$ & & $(6)$ & \\
\hline \multicolumn{24}{|c|}{ Transactions Costs } \\
\hline STT Index & 0.4 & 0.4 & & 0.4 & $* *$ & 1.1 & $* *$ & 0.2 & & 0.7 & & 0.1 & & 1.1 & & 0.0 & & 0.1 & & 0.8 & & 1.0 & $*$ \\
\hline$\Delta O R$ & 1.5 & 1.5 & & 1.5 & & 3.0 & & 1.2 & & 2.0 & & 1.1 & & 3.0 & & 1.0 & & 1.1 & & 2.2 & & 2.7 & \\
\hline \multicolumn{24}{|c|}{ Macroeconomic Variables } \\
\hline GDP Growth & $-2.0 \quad * * *$ & - & & - & & -3.7 & $* *$ & -3.3 & $* *$ & -4.6 & $* *$ & -0.6 & $* *$ & - & & - & & -0.6 & & -0.7 & * & -0.5 & \\
\hline Inflation & -6.8 & - & & - & & 11.2 & & 19.3 & & 16.6 & & -0.7 & & - & & - & & 0.1 & & 5.3 & & 3.8 & \\
\hline Real Interest Rate & 0.5 & - & & - & & 35.5 & * & 17.3 & $*$ & 48.6 & * & 5.7 & $* *$ & - & & - & & 10.4 & ** & 9.3 & $* *$ & 9.8 & ** \\
\hline \multicolumn{24}{|c|}{ Banking Variables } \\
\hline Private Credit & - & 0.7 & & - & & - & & 0.6 & & 0.7 & & - & & 0.4 & & - & & - & & 0.4 & & 0.3 & \\
\hline Total deposits & - & 0.5 & & - & & - & & - & & - & & - & & 1.2 & & - & & - & & 0.8 & & - & \\
\hline Liquid Assets & - & -0.2 & & - & & - & & 0.7 & & - & & - & & -1.1 & & - & & - & & -0.6 & & 0.7 & * \\
\hline Net Interest & - & -0.1 & & - & & - & & 0.0 & & - & & - & & 0.2 & & - & & - & & -0.4 & & - & \\
\hline Bank Costs & - & 0.9 & $* *$ & - & & - & & 1.2 & * & 0.6 & & - & & 0.6 & $* * *$ & - & & - & & 0.5 & $* * *$ & - & \\
\hline \multicolumn{24}{|l|}{ Stock Markets } \\
\hline Capitalization & - & - & & -0.5 & & 1.6 & * & - & & 0.6 & & - & & - & & -0.4 & & 0.4 & & - & & -0.6 & \\
\hline Value Traded & - & - & & 0.6 & & - & & - & & 1.1 & & - & & - & & 0.7 & & - & & - & & 1.1 & \\
\hline Stock Turnover & & & & -0.3 & & 1.2 & * & & & & & & & & & -0.4 & & 0.4 & & & & -0.6 & \\
\hline Price Volatility & - & - & & 1.2 & $* * *$ & 3.0 & $* * *$ & - & & 3.0 & * & - & & - & & 0.5 & $* * *$ & 0.6 & $* * *$ & - & & 0.7 & *** \\
\hline Dev. Expl. $(\%)^{*}$ & 27.9 & 29.0 & & 41.5 & & 74.6 & & 57.3 & & 75.5 & & 9.7 & & 17.3 & & 16.0 & & 25.3 & & 26.6 & & 36.8 & \\
\hline Success Rate ${ }^{\dagger}$ & 95.2 & 94.7 & & 96.1 & & 97.2 & & 95.9 & & 96.9 & & 95.8 & & 95.7 & & 95.4 & & 95.4 & & 94.7 & & 95.6 & \\
\hline Accuracy ${ }^{\ddagger}$ & 75.0 & 100 & & 83.3 & & 87.5 & & 83.3 & & 85.7 & & 0.0 & & 100 & & 50.0 & & 50.0 & & 50.0 & & 60.0 & \\
\hline Sensibility $^{\S}$ & 27.3 & 25.0 & & 45.5 & & 63.6 & & 55.6 & & 66.7 & & 0.0 & & 18.2 & & 14.3 & & 14.3 & & 18.2 & & 23.1 & \\
\hline
\end{tabular}

Notes: Maximum likelihood estimates of equation (2). Symbols ${ }^{* * *}$ and ${ }^{* * *}$ indicate statistical significance of a parameter at the $10 \%, 5 \%$ and $1 \%$ levels, respectively. $\triangle O R$ is the change in the odds ratio resulting from a one-unit change in $S T T$.

* "Deviance Explained" Goodness of Fit Criterion.

$\dagger$ Fraction of events (No Crisis or Crisis) correctly predicted by the model.

$¥$ Fraction crisis predictions that were realized.

$\S$ Fraction of realized crises correctly predicted by the model. 
Tél. : 514-985-4000 • Téléc. : 514-985-4039

www.cirano.qc.ca・info@cirano.qc.ca 